\title{
Trends of out-mobility from large housing estates in Stockholm: influences of the housing policy and neighbourhood context
}

\author{
Kati Kadarik $^{1}$ (D) Anneli Kährik ${ }^{1}$
}

Received: 5 May 2020 / Accepted: 7 May 2021 / Published online: 4 June 2021

(C) The Author(s) 2021

\begin{abstract}
Since 1990s Stockholm housing market has seen deregulations in accordance with liberalization trends in other European welfare states. The new governance principles together with increasing immigration and public rental housing conversions into cooperative housing in attractive inner city areas have put pressure on still rental-dominated estates because fewer rental dwellings must now cater to expanding numbers of people who have little choice on the housing market. In recent decades, many estates have displayed increasing signs of stigmatization, social exclusion, and outflow of relatively affluent people. This paper improves our knowledge of how the housing policy and economic changes have affected out-mobility from the housing estates in case of three cohorts of young people and how the childhood neighbourhood conditions affect this. Individual annual Swedish registry data (1990-2014) are employed to longitudinally study the out-mobility patterns of three cohorts that grew up in the estates against the backdrop of marketization, growing inequality and deteriorating conditions. This study supplements the existing literature on housing estates by clarifying how income has become more and ethnicity less important over time in explaining sorting patterns from these estates. However, the combination of the two has determined sorting throughout the study period. Growing up in a higher socioeconomic status neighbourhood had modest impact on reducing socioeconomic differences in out-mobility from the estates, while leading to more sorting based on ethnic background.
\end{abstract}

Keywords Residential mobility $\cdot$ Neighbourhood change $\cdot$ Neighbourhood context . Marketization $\cdot$ Large housing estates $\cdot$ Stockholm

\section{Introduction}

There has been a strong policy and academic interest in Europe in large housing estates (LHEs) (e.g. Andersson \& Bråmå, 2018; Kährik \& Tammaru, 2010; Musterd, 2008; Ronald van Kempen et al. 2005; Wassenberg, 2004) and in selective residential mobility

Kati Kadarik

kati.kadarik@ibf.uu.se

1 Uppsala University, Uppsala, Sweden 
related to those areas (Bråmå \& Andersson, 2005; Friedrichs, 1991; Musterd \& van Kempen, 2007). Housing estates which were built after WWII to address housing shortages and provide better and more modern housing conditions for large groups of people now face a multitude of problems and are the subject of much political debate in many countries (Dekker \& Van Kempen, 2004). In Sweden there is a political concern about the development trajectories of the estates, related to the 'fear' of the long-term consequences of social exclusion and residential segregation (Öresjö et al. 2004). Since the 1990s deregulations and marketization reforms in the Stockholm housing market have affected the socioeconomic situation in LHEs in particular. Moreover, there is a growing stigma connected to these areas, and to the people living in it - both in Sweden and elsewhere in Europe (Backvall, 2019; Dean \& Hastings, 2000; Grundström \& Molina, 2016; Hastings, 2004).

The existing studies in Sweden cover different aspects to disentangle the residential dynamics in LHEs (Bråmå, 2006; Bråmå \& Andersson, 2005, 2010; Macpherson \& Strömgren, 2013; Vogiazides, 2018; Vogiazides \& Chihaya, 2020). However, these studies are either lacking the longitudinal perspective, and/or neglect the aspect of neighbourhood histories and intergenerational mobility. However, the neighbourhood histories (e.g. the exposure time) and the intergenerational transmission of neighbourhood conditions, have received an overall increasing scholarly interest in neighbourhood research, as they have proved to be important determinants of predicting the individuals' mobility patterns and neighbourhood careers (e.g., Galster \& Sharkey, 2017; Krysan \& Crowder, 2017; Manley et al. 2018; van Ham et al. 2014). For example, van Ham and Manley (2012) refer to the importance of examining the life course perspective longitudinally, while also incorporating exposure time as an explanatory parameter in neighbourhood studies.

In our study, we aim to overcome this aspect when tracking residential choices in adulthood of three cohorts of young people that grew up in Stockholm's LHEs in different macroeconomic, housing market and neighbourhood conditions. With such approach, we aim to not only find out the residential long-term outcomes of being exposed to low-income neighbourhoods contexts during early life course stages, but also to understand the links between these neighbourhood effects and the prevailing housing policy/economic conditions. We ask 'what are the indicative implications of these structural changes on the 'inheritance' of residential contexts from parents to their children? Moreover, we ask 'how do these impacts vary across groups of individuals based on ethnic and socio-economic background', and 'does the childhood neighbourhood context matter for the residential outcomes of young people'?

As for the 'residential outcome', we refer to whether a person has moved out from any of the LHEs to other residential areas in Stockholm region when becoming an adult. The experience of following a particular life course stage influences needs and desires of individuals regarding housing and neighbourhood choice. Moreover, employment frequencies and income generally vary by age, as do available housing opportunities. Therefore, we focus our analysis on one age group-young people in their late twenties at the start of their housing careers (and we call them 'young adults' in the following analysis).

Different marketization measures were introduced step-by-step in the Swedish housing scene since 1991, and substantial macroeconomic changes took place throughout the 1990s and 2000s. The analytical focus on comparing the residential outcomes of the three cohorts of adolescents (18-19 years old) who lived in their parental homes in LHEs in 1990, 1997, and 2004 will enable to track the indicative influence of these accumulative structural changes on individual residential outcomes. Residential outcomes are being measured and classified a decade later-at age 28-29 years. The paper employs longitudinal Swedish 
registry data (from 1990 to 2014) for the analysis, and scalable individualized neighbourhoods to capture the variation within the LHEs.

\section{Main drivers of residential mobility}

Residential mobility is generally viewed from the perspective that a mismatch between a household's needs, expectations, preferences and current housing circumstances leads a household to move its place of residence (Rossi, 1955; Speare, 1974). The experiences of different life course stages (and especially transitions from one to another) serve as important predictors for residential mobility (Clark \& Onaka, 1983; Mulder, 1993). From the constraints' point of view residential mobility is determined by the availability of resources, especially by income (Brown \& Moore, 1970; Clark et al. 2006). But next to financial resources various other forms of capital influence access to housing, such as social (i.e., information and networks) and cultural (i.e., education and housing market knowledge) (Bolt et al. 2008; Boterman, 2012; Krysan \& Crowder, 2017). Young people with not so developed forms of capital exhibit risks to become trapped in more precarious housing segments and to suffer several setbacks (Hochstenbach \& Boterman, 2015). In addition, the availability of supportive social networks in one's neighbourhood-especially important for ethnic minorities and low-income households, may lower incentive for moving, or lead to residential choices where the supportive clusters exist (Kadarik et al. 2021; Miltenburg, 2015; Phillips, 2006). The level of residential clustering tends to be especially high for migrants upon arrival, especially when arriving from a low-income country (Macpherson \& Strömgren, 2013), but the longer duration of residing in a certain neighbourhood also seems to decrease the incentive to move (Vogiazides, 2018). However, a better housing market position at the start of the housing career in a new country can facilitate spatial integration (Kadarik, 2020).

Growing scholarly interest relates to the importance of parental social, economic, housing and neighbourhood situation on the residential careers of their children, referring to the 'inheritance' of housing and neighbourhood conditions-e.g. those growing up in neighbourhoods with high poverty levels being more likely to live in similar neighbourhoods later in life than someone who grew up in a different kind of neighbourhood (Galster \& Sharkey, 2017; Hedman et al., 2015; Krysan \& Crowder, 2017; Manley et al. 2018; van Ham et al. 2014; Vartanian et al., 2007). As such the spatial opportunity structures, including neighbourhoods, can be seen as (re)producers of intergenerational inequality (Galster $\&$ Sharkey, 2017). The direct effect of within-family income and housing-related transfers becomes especially important in the context of less regulated housing regimes influencing young people's housing careers, while also (re)producing patterns of inequality (Christophers, 2018).

The overall role of the neighbourhood in explaining residential mobility has been studied by many scholars (e.g. Feijten \& van Ham, 2009; Kearns \& Parkes, 2003). Both the neighbourhood's ethnic (Clark, 1992; Crowder, 2000) as well as socioeconomic composition tend to influence mobility patterns (Clark \& Coulter, 2015). Moreover, neighbourhood change over time is arguably an important explanatory factor for residential mobility (Lee et al. 1994; Schaake et al. 2010). Studies indicate that people have a strong preference for homophily and they want to live in a neighbourhood where their own characteristics are similar to those of their neighbours (e.g. Finney \& Simpson, 2009; Galster \& Turner, 2017; Musterd et al. 2016). Therefore, neighbourhood's change may trigger out-mobility of 
certain groups of residents (the research originated from U.S. where it was referred to as 'white flight') (Goering, 1978; Schelling, 1969).

There is also evidence that the overall neighbourhood deprivation is associated with preferences for moving (Clark \& Coulter, 2015; van Ham \& Clark, 2009). Connected to this is the 'racial proxy hypothesis', arguing that people want to leave 'ethnic-concentration' neighbourhoods not because of racially motivated preferences but because these neighbourhoods are often deprived (Crowder, 2000; Ellen, 2000; Harris, 1999). Neighbourhood decline tends to increase the wish to move, but reduces the actual mobility when the overall housing opportunities as well as resources are limited (Kearns \& Parkes, 2003).

Contextual embeddedness in terms of macroeconomic situation and institutional regulations, but also in regards to urban policies and the diversity of the housing stock, result in multiple implications on residential mobility (e.g. Boterman \& van Gent, 2014; Teernstra $\&$ van Gent, 2012). Economic recessions have been associated with increasing the levels of intra-urban and regional patterns of inequality, and concentration of poverty, especially to the suburban locations (Andersson \& Hedman, 2016; Hochstenbach \& Musterd, 2018; Musterd, 2005).

Market regulated housing regimes tend to increase the importance of individual wealth and intergenerational influence on residential careers, resulting in growing socio-spatial sorting as well as long term persistence of housing wealth and poverty situations (Bailey et al. 2017; Marcińczak et al. 2016; Musterd, 2014). During the last three decades many countries have adopted neoliberal reforms, resulting in the overall promotion of homeownership and the reduction of affordable rental housing and housing subsidies (Andersson \& Magnusson Turner, 2014; e.g. Hochstenbach, 2017). In both Europe and U.S., policies to promote social mix and the renewal of disadvantaged low income neighbourhoods have been applied, however the policies often leading to the reduction of housing affordability as well as state-led gentrification processes (e.g. Doucet, 2014; Lees, 2008).

\section{Changing housing regime, economic restructuring, and population influx influencing residential dynamics in Stockholm}

From the 1930s to the 1990s public rental housing in Sweden was a key element in public policies to secure a high-quality affordable housing for all (Elander, 1991). The housing system, catering the needs of the broad working and middle classes, became a pillar of the Swedish social democratic welfare state (Clark \& Hedin, 2009; Turner \& Whitehead, 2002). Yet, the shift from regulated to market prices in the tenant-owned apartment sector (bostadsrätt) already introduced the marketization processes in the Swedish housing system as early as 1968 (Christophers, 2013). The marketization reforms greatly intensified when the liberal-conservative government came to power in 1991, and these were further accelerated by the need for austerity policies due to the economic crisis of the $1990 \mathrm{~s}$ (Andersson \& Kährik, 2016).

The main political shift was the marketization of the public rental sector (allmännytta) which had two main stages. First, in the early 1990s the national government allowed local governments to convert public rental housing into both market-based tenant-owned housing (i.e., cooperatives) and into private rental accommodation. Second, from 2011 municipal housing companies began to operate on business like principles competing on the market just as private rental companies (Christophers, 2013). 
Among the arguments behind implementing the privatisation strategies were the need to fight social exclusion and increase social mix in neighbourhoods (Andersson \& Magnusson Turner, 2014). Stockholm has been the most prominent advocate for tenure conversions (Andersson \& Bråmå, 2018). As a result of these changes, public housing stock in Stockholm was reduced from 32 to 18 percent during 1990-2010 (Andersson \& Magnusson Turner, 2014). However, the conversions have been highly spatially selective concentrating overwhelmingly in the inner city neighbourhoods where economic gains have been higher (Andersson \& Magnusson Turner, 2014; Hedin et al. 2012). While the inner city experienced the decline in rental housing from 73 to 36 percent (from 19 to $7 \%$ in case of public housing) during 2000-2010, the suburban housing estates had a fall only from 70 to 65 percent (from 62 to $39 \%$ in case of public housing) over the same period (Andersson \& Kährik, 2016).

Bråmå and Andersson (2010) have argued that residential patterns in the Swedish metropolitan areas are increasingly explained by changes in these tenure patterns. The inflation in housing prices and increasing unaffordability in the capital city region has been further accelerated by the rapid influx of foreign population. The population with the foreign background (i.e., born abroad or born in Sweden with both parents born abroad) has especially increased in LHEs - from 37 per cent in 1990 to 66 per cent in 2014 (Andersson \& Bråmå, 2018).

\section{The social and ethnic dynamics in the LHEs of Stockholm}

In Sweden, LHEs are often synonymous with housing built as part of the Million Homes Programme, which entailed the construction of one million new dwellings all over Sweden between 1965 and 1974. The rationale of the policy was similar to those of comparable programmes in other countries in Europe, for example, to resolve housing shortages, modernize the housing stock, and improve standards of living (Andersson \& Bråmå, 2018). The foreign-born residents settled in these estates more often than natives, due to the influx of foreign labour force at the time of their construction, and the availability of public rental flats (Andersson \& Bråmå, 2018).

Social and political changes since the 1990s (neoliberalization, transition to the service economy) have intensified spatial segregation and tenure segmentation in Stockholm's housing market (Andersson \& Kährik, 2016; Hedin et al. 2012; Scarpa, 2016). Most Stockholm housing estates did well in socioeconomic terms until 1990. Since then poverty and urban problems have gradually become suburbanised and concentrated to the large housing estates (those built between the 1960s and 1970s) (Andersson \& Bråmå, 2018; Andersson \& Kährik, 2016; Malmberg et al. 2013). There are discussions of 'middle-class leakage' from these estates, leading to the abandoning of LHEs by more stable and affluent households (Andersson \& Bråmå, 2004). The options for low income households have worsened due to shortage of rental housing especially in areas outside LHEs, as well as due to increasingly inaccessible housing prices in other tenure sectors.

The ethnic segregation in Swedish cities has a racially selective character, meaning that it is mostly the groups with non-European backgrounds who become concentrated in LHEs (Grundström \& Molina, 2016). The growing ethnic minority density and the socioeconomic dynamics in combination make these neighbourhoods less attractive to native Swedes (Öresjö et al. 2004), but also the ethnic minorities who started their residential 
career in LHEs with better socioeconomic standing, facilitated by the partnership with natives, tend to move away from these areas (Macpherson \& Strömgren, 2013; Vogiazides, 2018).

Publicly, the suburban LHEs are considered to be at the lowest level of the housing hierarchy in Stockholm. Deeply rooted poor reputations have led to the stigmatization processes affecting educational prospects, sense of 'otherness', and self-esteem of young minorities among other aspects (Dean \& Hastings, 2000; Johansson \& Olofsson, 2011; Sernhede, 2011). The stigmatization and increasing social exclusion in LHEs has been argued to be the result of changes in housing and welfare policies (Alm Fjellborg, 2018; Andersson \& Kährik, 2016; Grundström \& Molina, 2016), as well as changed preferences as regards physical layout of the estates, aesthetic values and neighbourhood qualities (Öresjö et al. 2004). The rapidly growing foreign-background population and related racialization (Grundström \& Molina, 2016), as well as growing metropolitan inequality levels in itself have become risk factors for the future developments in LHEs.

\section{Data and methods}

The data used in this paper is based on Swedish registers and was compiled by Statistics Sweden. The data is available yearly for the entire population of Sweden from 1990 to 2014, and it contains information on individuals' financial situation, education, work status, family status, residential geography and housing characteristics, as well as individuals' parents.

The study population is all young adults (18-19 years old) who lived with their parents in multifamily housing in LHEs of Stockholm County in any of the three years: 1990, 1997, or $2004\left(t_{1}\right)$. The selection of LHEs was defined based on Andersson and Bråmå's (2018, p. 365) definition of 'a major concentration of multifamily housing constructed in the 1951 to 1990 period' which refers to a statistical area (SAMS) with at least 1000 dwellings where $75 \%$ or more of the residents live in multifamily housing. The study population is confined to the 49 housing estates which were identified (based on 'SAMS' division), which mostly locate $10-20 \mathrm{~km}$ from the city centre along the main highways and subway lines (Fig. 1).

The total number of people living in Stockholm's LHEs has increased over time, but decreased relative to Stockholm County's total population increase (Table 1). The number of 18-19 year olds living in LHEs has increased in both absolute and relative terms, and this age group has been overrepresented in LHEs in all 3 years.

Up to 1990 , socioeconomic conditions in the 49 LHEs differed little from the average in the Stockholm region, whereas by 2014 the situation had worsened. While in 1990 the employment rate was $80 \%$ in the estates and $85 \%$ in Stockholm County, whereas by 2014 the rates were $66 \%$ and $79 \%$ respectively (Andersson \& Bråmå, 2018). Analysing the disposable income distribution in LHEs compared to the rest of Stockholm County, the changes over time (1990-1997-2004) are as expected. The lowest income groups have increased over the period at the expense of the middle and higher income groups (Table 2) meaning that the LHE population has become increasingly poor compared with the rest of the County.

The cohort individuals included in the sample are followed up 10 years later when they are 28-29 years old, in 2000, 2004, and $2014\left(t_{2}\right)$. The study limits the analyses to intraurban stayers and movers by excluding all those who left Stockholm County during the 


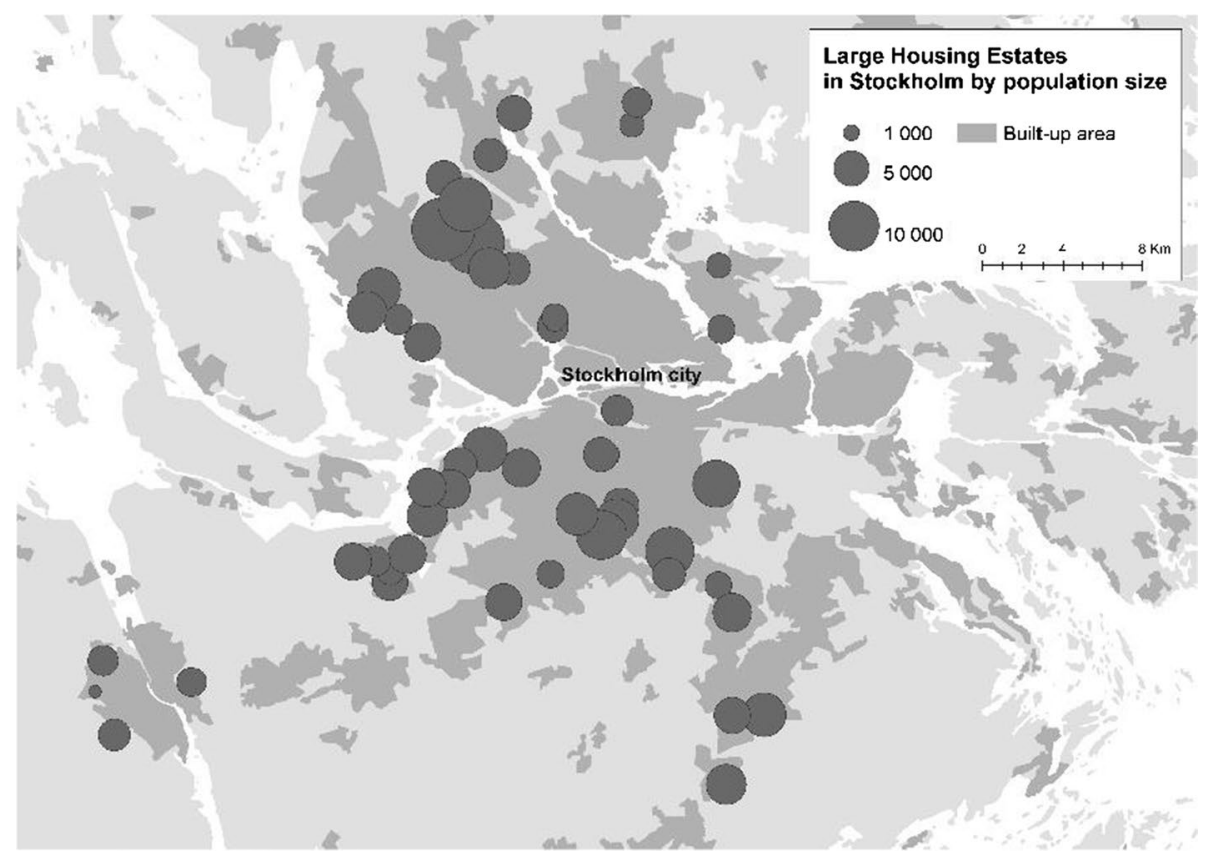

Fig. 1 Location of large housing estates in Stockholm by population size in 2004

Table 1 Cohorts included in the study relative to Stockholm County's population and multifamily housing population

\begin{tabular}{|c|c|c|c|c|c|c|}
\hline \multirow[t]{2}{*}{ Cohort } & \multicolumn{2}{|c|}{$\begin{array}{l}N \text { in multifamily } \\
\text { housing in large } \\
\text { housing estates }\end{array}$} & \multicolumn{2}{|c|}{$\begin{array}{l}\% \text { of Stockholm } \\
\text { County popula- } \\
\text { tion }\end{array}$} & \multicolumn{2}{|c|}{$\begin{array}{l}\% \text { of Stockholm } \\
\text { County multi- } \\
\text { family housing } \\
\text { population }\end{array}$} \\
\hline & All & Age $18-19$ & All & Age 18-19 & All & Age $18-19$ \\
\hline 1990 & 249,781 & 5942 & 16.2 & 14.8 & 26.1 & 31.5 \\
\hline 1997 & 272,352 & 5691 & 16.2 & 16.4 & 25.9 & 32.0 \\
\hline 2004 & 277,620 & 6624 & 15.5 & 17.0 & 25.3 & 31.9 \\
\hline
\end{tabular}

follow-up period. The 18-19-year-old group is used because its members are about to finish their upper secondary school studies and leave their parental homes to start their independent housing careers. Their residential location is examined when they are 28-29 years old, because by then most of young people have finished studying, are active in the labour market, and have a more stable housing situation as compared to the years in between.

By selecting the study population as of 1990, 1997, and 2004, it is possible to capture the neighbourhood careers under different political and economic circumstances: $(i)$ the 1990 cohort relating to still rather modest inequality levels in spatial terms in $t_{1}$, however under the influence of the economic recession between $t_{1}$ and $t_{2}$, but experiencing economic boom times in $t_{2}$; (ii) the 1997 cohort growing up in the LHEs during the crisis years and being affected by the applied marketization measures when entering the housing market; and (iii) the 2004 cohort who has grown up during the economic boom period, experiencing more unequal socioeconomic situation as compared to the former cohorts, and meeting 
Table 2 Disposable income (equalized household disposable income) quintile distribution in large housing estates (LHEs) and all other residential locations in Stockholm County in the cohort selection years, i.e., 1990, 1997, and 2004 (total Stockholm County population)

\begin{tabular}{|c|c|c|c|c|}
\hline Year & $\begin{array}{l}\text { Disposable } \\
\text { income quintile }\end{array}$ & Outside LHEs & LHEs & Stockholm, total \\
\hline \multirow[t]{6}{*}{1990} & 1 & 19.9 & 20.6 & 20.0 \\
\hline & 2 & 19.3 & 23.8 & 20.0 \\
\hline & 3 & 19.3 & 23.9 & 20.0 \\
\hline & 4 & 19.9 & 20.7 & 20.0 \\
\hline & 5 & 21.6 & 11.0 & 20.0 \\
\hline & Total & 100.0 & 100.0 & 100.0 \\
\hline \multirow[t]{6}{*}{1997} & 1 & 19.1 & 25.2 & 20.0 \\
\hline & 2 & 18.9 & 26.0 & 20.0 \\
\hline & 3 & 19.5 & 22.5 & 20.0 \\
\hline & 4 & 20.5 & 17.4 & 20.0 \\
\hline & 5 & 22.0 & 9.0 & 20.0 \\
\hline & Total & 100.0 & 100.0 & 100.0 \\
\hline \multirow[t]{6}{*}{2004} & 1 & 18.9 & 26.2 & 20.0 \\
\hline & 2 & 18.7 & 27.1 & 20.0 \\
\hline & 3 & 19.5 & 23.0 & 20.0 \\
\hline & 4 & 20.6 & 16.3 & 20.0 \\
\hline & 5 & 22.2 & 7.4 & 20.0 \\
\hline & Total & 100.0 & 100.0 & 100.0 \\
\hline \multirow[t]{5}{*}{$\%$ net change, $1990-2004$} & 1 & -1.0 & 5.6 & \\
\hline & 2 & -0.6 & 3.3 & \\
\hline & 3 & 0.2 & -0.9 & \\
\hline & 4 & 0.7 & -4.4 & \\
\hline & 5 & 0.6 & -3.6 & \\
\hline \multirow{6}{*}{$\begin{array}{l}\text { Population numbers, net change in } \\
\% \text { per quintile, 1990-2004 }\end{array}$} & 1 & 7.4 & 40.1 & 12.5 \\
\hline & 2 & 9.8 & 25.7 & 12.7 \\
\hline & 3 & 14.6 & 5.7 & 13.0 \\
\hline & 4 & 17.1 & -13.4 & 12.3 \\
\hline & 5 & 16.2 & -25.8 & 12.7 \\
\hline & Total & 13.1 & 10.2 & 12.6 \\
\hline
\end{tabular}

Note: cases with missing values are excluded

Table 3 Time points used in the study and the cohorts' ages during the banking crisis

\begin{tabular}{|c|c|c|c|c|c|}
\hline Cohort & Born & $\begin{array}{l}\text { Age as of the bank } \\
\text { crisis, } 1992\end{array}$ & $\begin{array}{l}\text { Life stage during the } \\
\text { crisis years, 1992-1997 }\end{array}$ & $\begin{array}{l}\text { Time } 1\left(t_{1}\right) \\
18-19 \text { years old }\end{array}$ & $\begin{array}{l}\text { Time } 2\left(t_{2}\right) \\
28-29 \text { years } \\
\text { old }\end{array}$ \\
\hline 1 & 1971-1972 & $21-20$ years old & Adult & 1990 & 2000 \\
\hline 2 & 1978-1979 & 13-14 years old & Teenager & 1997 & 2007 \\
\hline 3 & 1985-1986 & 6-7 years old & Childhood & 2004 & 2014 \\
\hline
\end{tabular}


the most competitive housing market situation when becoming adults (Table 3). Studying migration over periods should make the results robust.

Binary logistic regression models are employed to estimate the selective out-mobility from LHEs. Out-mobility refers to that the individual is not living in any of the LHE areas 10 years later when she or he is $28-29$ years old. The results are reported as average marginal effects $(d y / d x$ calculated using the margins command of STATA). Average marginal effects (AMEs) facilitate comparisons across models (Mood, 2010). The models include controls for various individual, parental and neighbourhood characteristics. Income and ethnic differences have been the most frequently mentioned drivers for sorting into neighbourhoods-first, as money buys choice on the housing market and immigrants often have weaker financial situation; second, neighbourhood preferences as well as experiences of discrimination on the housing market differ among ethnic groups (e.g., Bolt et al., 2008; Kauppinen \& Vilkama, 2016; Tammaru et al., 2015; Vogiazides, 2018). The importance of intergenerational transmission of socio-economic and neighbourhood context was discussed previously (e.g., Hedman et al., 2015; Sharkey, 2008; van Ham et al., 2014). As pointed out earlier, residential mobility is also related to life course and demographic factors (e.g. Mulder, 1993). Both the neighbourhood's ethnic (Clark, 1992; Crowder, 2000) as well as socioeconomic composition tend to influence mobility patterns (Clark \& Coulter, 2015). Based on these arguments the set of individual, parental and neighbourhood conditions were selected for the models.

Parental characteristics (i.e., employment, education level, and property type) were measured for the cohorts when they were 18-19 years old $\left(t_{1}: 1990,1997\right.$, and 2004) and the individual characteristics (i.e., education level, employment, family status, and income) were measured at follow-up 10 years later $\left(t_{2}: 2000,2007\right.$, and 2014). As the full population is used, the models do not suffer from sampling error and conventional significance tests are not relevant to the data.

The first part of the analysis thus focuses on investigating the out-mobility probability (and the trends over periods) for ( $a$ ) those having a non-Western background (in LHEs the group with non-Western background has increased substantially over the years, increasing from $18.9 \%$ in cohort 1 to $48.1 \%$ in cohort 3$),{ }^{1}(b)$ those having a low income in adulthood $\left(t_{2}\right)$ (i.e., belonging to the bottom $20 \%$ of the income distribution), and (c) those belonging to both of these categories. Previous research has shown that, overall, the 'lock-in' effect in distressed neighbourhoods is greatest for these groups (Andersson, 2013; Andersson \& Bråmå, 2004).

The second part of the study examines in particular whether the selective mobility depends on the local neighbourhood context at the time of growing up.

Since there are differences between and also within LHEs, this paper employs smaller individualized neighbourhood units to account for this heterogeneity-we use bespoke neighbourhoods based on the 400 nearest neighbours of every resident. ${ }^{2}$ Following the example of Wessel et al. (2017), a local neighbourhood status measure (ranging from 1 to

\footnotetext{
1 A person of non-Western background is identified as someone born, or both of whose parents were born, in a non-Western country. Non-Western countries comprise countries outside Europe, North America, and Oceania.

2 The local neighbourhoods are calculated based on the residential geo-coordinates $(100 \times 100-\mathrm{m}$ grid $)$ of everyone residing in Stockholm County using a $k$-nearest neighbour algorithm and EquiPop software (Östh 2014). With the $k$-nearest approach to contextual characteristics, the risk of creating biased neighbourhood estimates is reduced (as an individual is placed in the centre of his or her local neighbourhood context) (Galster 2001; Hedman et al. 2015).
} 
10, where 1 represents the lowest status and 10 the highest status) is calculated based on three socioeconomic context variables: share of individuals who have higher education, are employed, and have high income.

\section{Out-mobility from LHEs and changes over cohorts}

With each successive studied cohort, more and more individuals who grew up in LHEs also lived there in adulthood: $40.5 \%$ of cohort 1 had not left (or returned to) the LHEs at age $28-29,44.3 \%$ of cohort 2 , and $48.6 \%$ of cohort 3. Leaving LHEs has thus become more difficult or less preferred over time for these young people.

To estimate how individual characteristics and neighbourhood composition affect the tendency to leave LHEs, a series of logistic regression models was run (see Table 4): the first two models include only variables measured at $t_{1}$; the third model addresses the first part of the study; and the fourth model addresses the second part of the study. Each coefficient in the model expresses the average difference in the probability of belonging to a group that the model is predicting compared with the reference group.

Belonging to either of the two defined risk groups (i.e., having a non-Western background or having low income) translates into a decreased probability of having moved from LHEs (Table 4). The control variables behave as expected: the attribute of being a male reduces the likelihood of leaving LHEs; while a stronger socioeconomic position at $t_{2}$ (i.e., having obtained higher education or being employed) increases the probability of having moved out. Having children in the household decreases the likelihood of having left— this is reasonable, as households with children are less mobile. Also, the socioeconomic situation of the parents (at $t_{1}$ ), plays a role. If both parents' highest education level is low, the children are less likely to move away from LHEs than are their counterparts, while both parents being employed has the opposite impact. Tenure does not result in statistically significant estimates. Out-mobility seems not to be much affected by whether one's childhood home was a rental apartment or owned (i.e., a cooperative)—so the parental housing tenure does not have a direct impact on moving out the LHEs.

Cohorts 2 and 3 have overall lower probabilities of leaving than does cohort 1 (Table 4). The probability of having left LHEs has decreased for both low-income individuals and others, but more so for individuals with low income (Fig. 2), meaning that the difference between these two groups has increased, and this is seen also from the average marginal effects (AMEs) (Fig. 3). The AME of low income has more than doubled from 4 percentage points to almost 9 percentage points, meaning that, all else being equal, for cohort one we would expect a 4-percentage-point decrease in the proportion of individuals who have moved out if we change the income variable from non-low income to low income, and that for cohorts two and three, having low income on average decreases the probability of having left LHEs by around 9 percentage points. Low income was thus a crucial factor that decreased the likelihood of out-mobility for those who grew up in LHEs during the worst years of the crisis and when the effects of marketization processes became visible (cohort two), but remains an important factor for cohort 3 too.

The probability of out-mobility has not changed much over the cohorts for individuals of non-Western background, but has decreased for 'other background' group (Fig. 4), meaning that the difference between these two groups has decreased, as also seen from 
Table 4 Logistic regression of out-mobility from large housing estates: average marginal effects $(d y / d x)$

\begin{tabular}{|c|c|c|c|c|}
\hline & Model 1 & Model 2 & Model 3 & Model 4 \\
\hline Non-Western background & & $-0.132 * * *$ & $-0.126^{* * *}$ & $-0.131 * * *$ \\
\hline Low income & & & $-0.076 * * *$ & $-0.074 * * *$ \\
\hline Neighbourhood status (continuous) & $0.018 * * *$ & 0.002 & & -0.002 \\
\hline \multicolumn{5}{|l|}{ Control variables } \\
\hline \multicolumn{5}{|l|}{ Individual, at $t_{2}$} \\
\hline Male & & $-0.050 * * *$ & $-0.052 * * *$ & $-0.052 * * *$ \\
\hline \multicolumn{5}{|l|}{ Education (ref: intermediate level) } \\
\hline Low & & $-0.041 * * *$ & $-0.041 * * *$ & \\
\hline High & & & $0.066^{* * *}$ & $0.066^{* * *}$ \\
\hline Employed & & & $0.057 * * *$ & $0.058 * * *$ \\
\hline Children living at home & & & $-0.123 * * *$ & $-0.125^{* * *}$ \\
\hline \multicolumn{5}{|l|}{ Parental, at $t_{1}$} \\
\hline Both parents employed & & $0.074 * * *$ & $0.054 * * *$ & $0.053 * * *$ \\
\hline Both parents with low level of education & & $-0.070 * * *$ & $-0.044 * * *$ & $-0.049 * * *$ \\
\hline Rental apartment (ref: cooperative) & & 0.001 & 0.010 & 0.012 \\
\hline \multicolumn{5}{|l|}{ Cohort (ref: cohort 1) } \\
\hline Cohort 2 & $-0.040 * * *$ & 0.002 & -0.004 & -0.013 \\
\hline Cohort 3 & $-0.083 * * *$ & $-0.033^{* *}$ & $-0.041 * * *$ & $-0.045^{* * *}$ \\
\hline \multicolumn{5}{|l|}{ Interactions } \\
\hline Non-Western background \# Cohort & & & Yes & No \\
\hline Low income \# Cohort & & & Yes & No \\
\hline Low income \# Non-Western background & & & Yes & No \\
\hline Low income \# Non-Western background \# Cohort & & & Yes & No \\
\hline Non-Western background \# Neighbourhood status & & & No & Yes \\
\hline Low income \# Neighbourhood status & & & No & Yes \\
\hline $\begin{array}{l}\text { Non-Western background \# Low income \# Neigh- } \\
\text { bourhood status }\end{array}$ & & & No & Yes \\
\hline$N$ observations & 13,082 & 13,082 & 13,082 & 13,082 \\
\hline Log likelihood & -8929 & -8736 & -8470 & -8476 \\
\hline Nagelkerke's pseudo $R^{2}$ & 0.019 & 0.057 & 0.108 & 0.107 \\
\hline
\end{tabular}

$* p<0.05, * * p<0.01, * * * p<0.001$

the AMEs (Fig. 5). The average marginal effect of having a non-Western background has decreased from around 17 percentage points to 8 percentage points (Fig. 5).

The interactions between low income and non-Western groups show that the smallest probability of having left LHEs is for individuals belonging to both risk groups, and this probability has slightly decreased for cohort 3 (Fig. 6). The highest probability of having left LHEs is for individuals belonging to neither risk group, and this probability has also decreased with time, but more. Thus, the difference between these two groups has decreased over time. Figure 6 also shows how out-mobility probabilities have changed when belonging to just one of the two risk groups: if for cohort 1 having low income translated into higher out-mobility probabilities than for non-Western background then for cohort 3 these probabilities are equal between these two groups. 


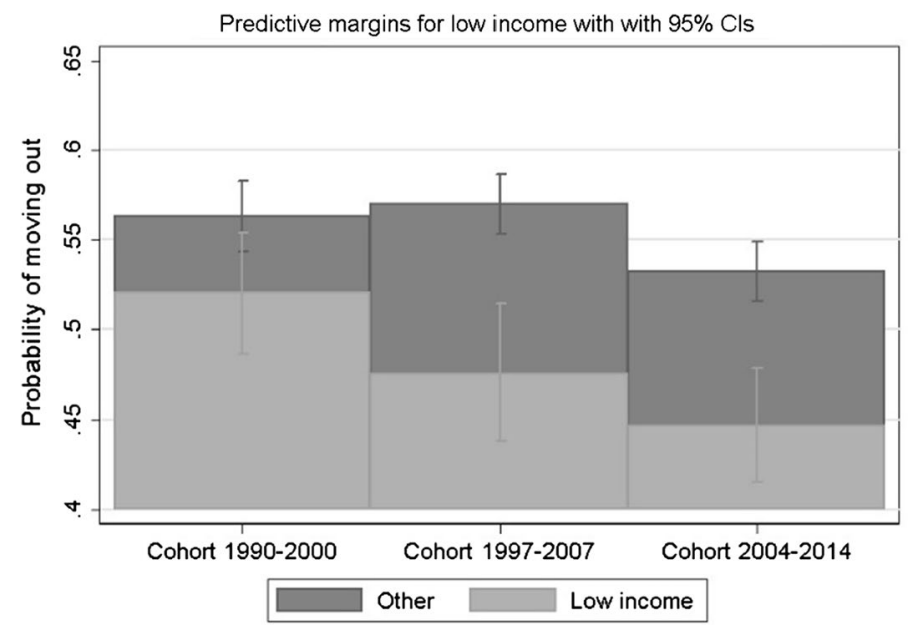

Fig. 2 Predictive margins of low income on out-mobility, across cohorts

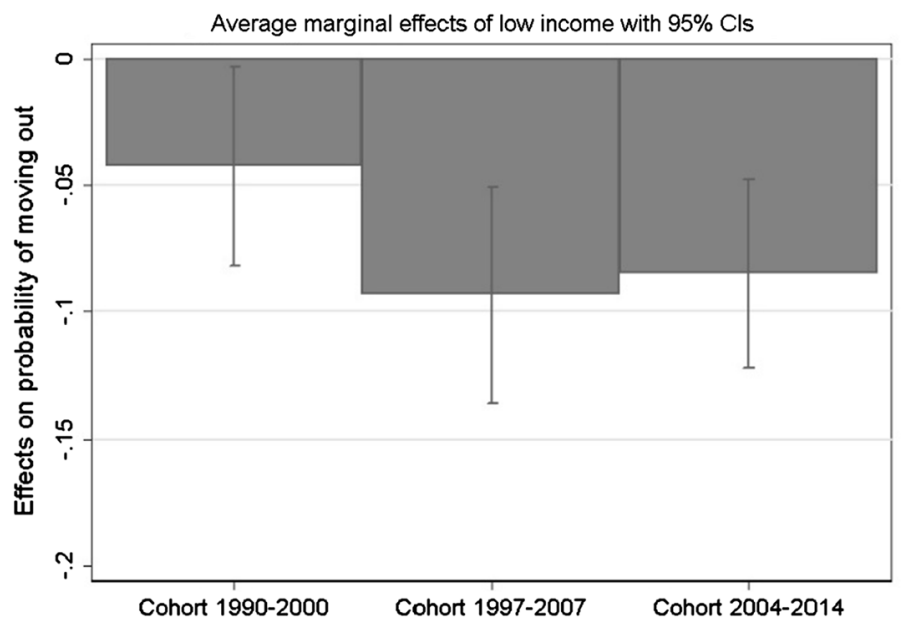

Fig. 3 Average marginal effects of low income on out-mobility, across cohorts

The second part of the analysis focused on measuring the impact of childhood neighbourhood status on out-mobility from LHEs. Increasing the childhood local neighbourhood status increases the overall probability of leaving LHEs (Table 4). Figure 7 shows that for individuals with low income, the probabilities of having left LHEs are slightly higher when she or he grew up in socioeconomically 'higher'-status neighbourhoods. For other income groups, growing up in socioeconomically higher-status neighbourhoods translates into slightly lower probabilities of having left LHEs. Therefore, the income-based sorting of who stays and who leaves is especially strong in case of those individuals who grew up in low social status neighbourhood conditions, leaving the least chances for out-mobility for the lowest income group. The chances for out-mobility are more equal for different socioeconomic status groups in case they grew up in higher status neighbourhoods. 


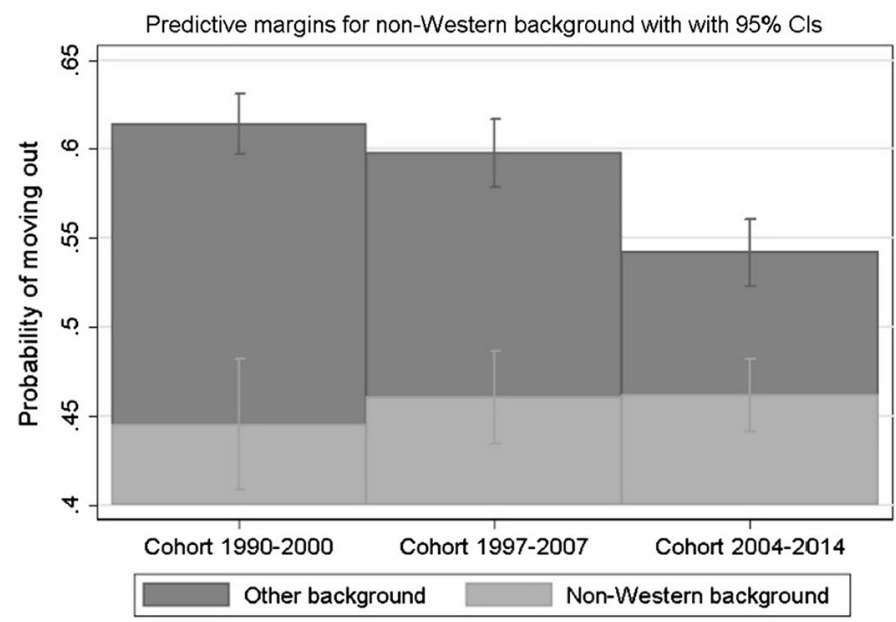

Fig. 4 Predictive margins of non-Western background on out-mobility, across cohorts

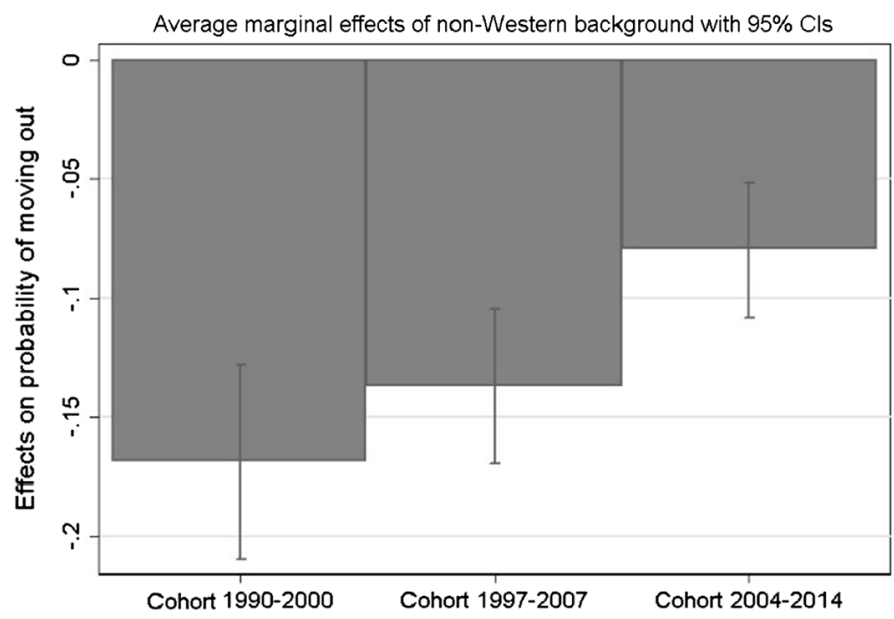

Fig. 5 Average marginal effects of non-Western background on out-mobility, across cohorts

Figure 8 shows that the childhood neighbourhood context tends to become more important determinant for out-mobility in case of different ethnic background groups. For people with non-Western background, the probabilities of having left LHEs are much lower (as compared to 'other background' groups) when they grew up in socioeconomically higher-status neighbourhoods. The difference between the two groupsnon-Western and other background-is smaller in socioeconomically lower-status neighbourhoods. 


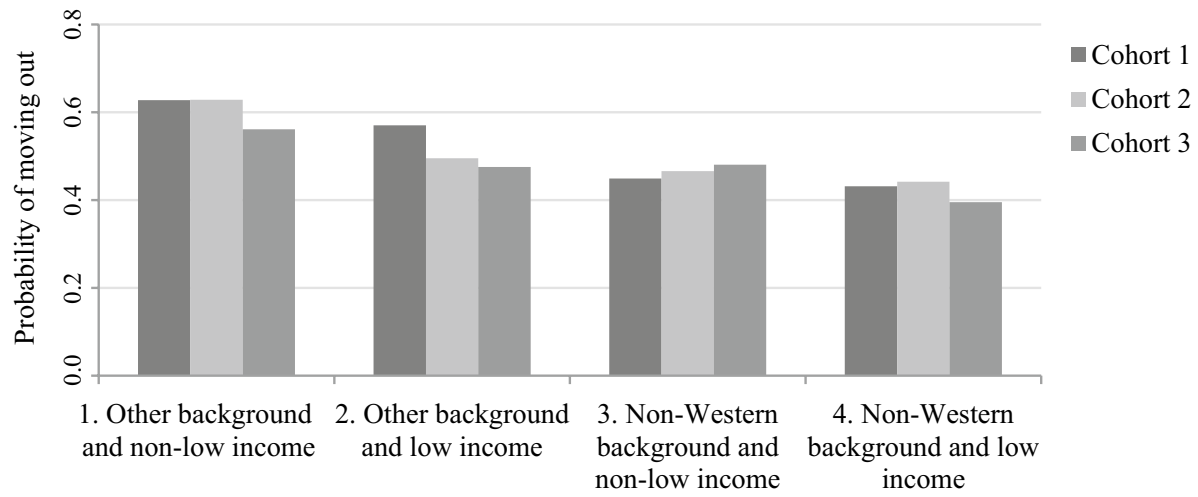

Fig. 6 Predictive margins for interactions between low income and non-Western groups, across cohorts

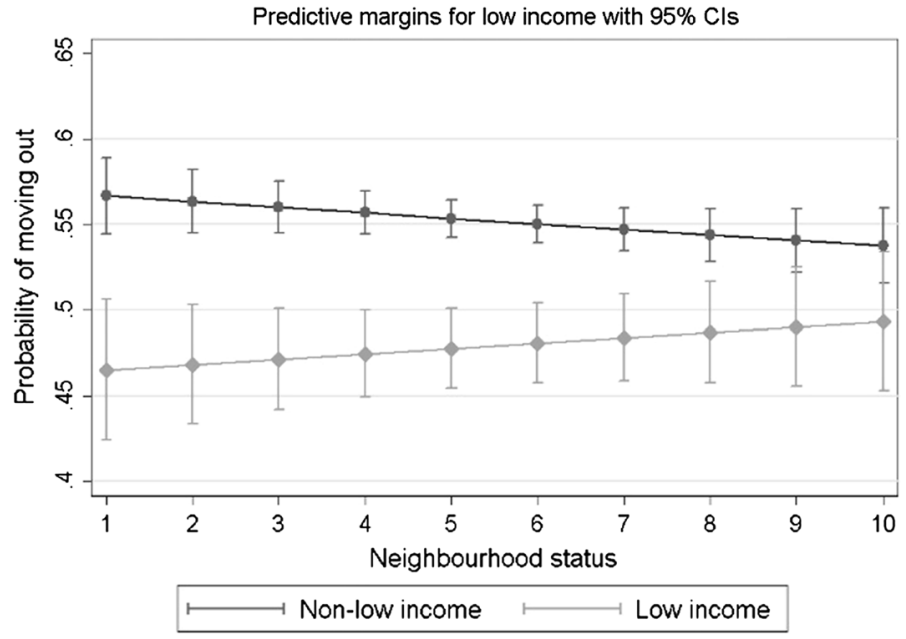

Fig. 7 Predictive margins of low income on out-mobility, depending on the childhood neighbourhood status

\section{Discussion}

Although welfare state transfers still play an important role in housing allocation and residential outcomes in Stockholm region, the housing market has gradually become to function much more on market-bases during the last decades. The previous generous state subsidies targeting the housing sector and households have been greatly reduced. Stockholm region in particular has witnessed a decreasing affordability of housing, rapid inflation in housing prices, and fast population growth. This has especially affected the access to housing for low-income people and immigrants who depend much more on lower cost rental housing. Poverty and urban problems have gradually become suburbanised and concentrated in the LHEs built during the 1960s-1970s (e.g. Andersson \& Bråmå, 2018). 


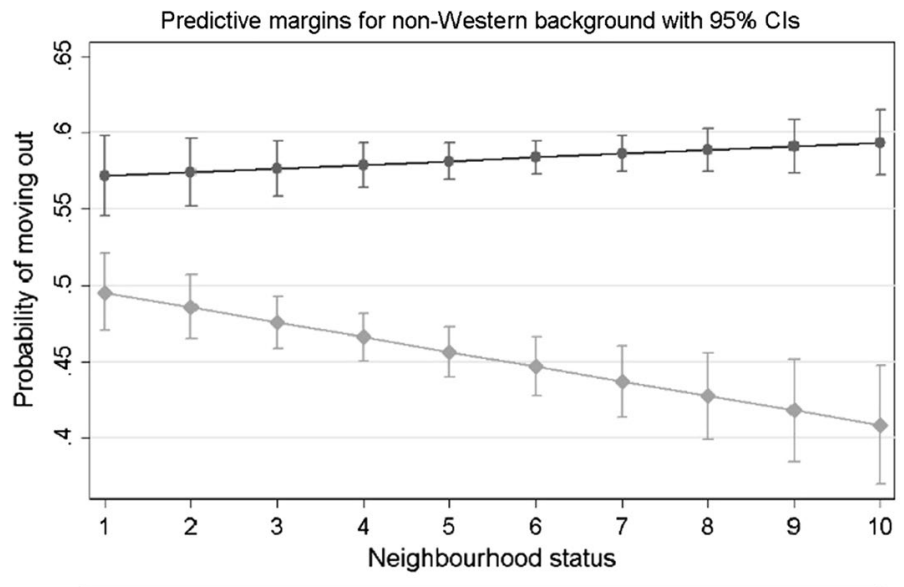

Other background

Non-Western background

Fig. 8 Predictive margins of non-Western background on out-mobility, depending on the childhood neighbourhood status

The focus of the current study was on the perspectives of out-mobility from LHEs in case of young adults who grew up in such neighbourhoods. As the previous research has pointed to the importance of neighbourhood histories in explaining residential mobility patterns (Manley et al. 2018; van Ham et al. 2014) the study also aimed at identifying the role of childhood neighbourhood conditions on the likelihood of out-mobility. Overall, as time passes from the introduction of marketization reforms, an ever-larger share of young adults who grew up in the LHEs still stay there in age 28-29 years. From the cohort who reached 28-29 years of age by 2014 every second young adult stayed put in LHEs. The harshness of the changing housing market makes out-mobility less common for everyone, not only for the most marginalized minorities. However, low income and the status of non-Western background have become additional risk factors reducing the chances of out-mobility from LHEs. Clearly those belonging to both risk groups are the ones with the lowest probability of out-mobility (c.f. Bråmå \& Andersson, 2005).

As compared to the ethnicity, income has become more important determinant for out-mobility over time when the outcomes for different cohorts are measured. Having low income has become an equally important determinant for being 'locked' in LHEs as belonging to the non-Western group. The results indicate that the marketization context in particular, associated with the reduction of housing affordability and increasing housing prices, puts more constraints on residential mobility (c.f. Tammaru et al. 2016). The improved macroeconomic conditions seem not to be able to overcome the inequalities caused by the marketization (welfare cuts, changes in tax system, spatially selective privatisation, and public municipal companies functioning on market bases). Over time the low-income groups rely more on the availability of public rental housing, which has become more spatially concentrated in suburban LHEs (Andersson \& Magnusson Turner, 2014).

Next to individuals' income also their parents' better socioeconomic situation in one's childhood translate into better opportunities for young people in the housing market. But also, the childhood neighbourhood status tends to have a modest impact on the 
selective out-mobility from LHEs. Sorting based on income status is greater for those who grew up in lower socioeconomic status neighbourhoods, leaving the low income earners from poor neighbourhood conditions the most trapped in LHEs. Thus, the neighbourhood status seems to become an extra resource to facilitate better neighbourhood careers in adulthood. On the contrary, better childhood neighbourhood conditions do not translate into better out-mobility chances for non-Western background groupswhen growing up in a better status neighbourhood the non-Western migrants will stay considerably more in LHEs than their counterparts in low status neighbourhoods. This could be an indication that people of non-Western background are more satisfied with their living environment if they grew up in higher-status neighbourhoods. More studies of this matter are needed to clarify the reasons underlying this sorting based on ethnicity.

Qualitative studies in the Nordic countries have found that to understand the residential patterns of minorities, constrained choice is more important than voluntary self-segregation (Søholt \& Lynnebakke, 2015). Swedish empirical studies have shown that LHEs serve more as springboards: most newcomers (especially non-Western migrants) in Sweden start their housing careers in LHEs, and those who succeed in society tend to leave these estates relatively quickly (Bråmå \& Andersson, 2005). Thus, while admitting the relevance of the preferences aspect and the preference for especially ethnic minorities to live nearby their social networks, this study confirms that the constraints' factor based on socioeconomic resources (involving intergenerational transmissions next to individual social status) is growingly important in explaining residential mobility trends in Stockholm housing market. Inequality patterns are growing in importance in explaining intra-urban mobility of young people out of whom an increasing part sees staying (or returning to) LHEs as the only option in the housing market.

Although LHEs are quite different in terms of physical layout and socioeconomic status, these inter-estate and inner-estate differences translate only to modest differences in terms of neighbourhood careers for young people.

Funding Open access funding provided by Uppsala University.

\section{Declaration}

Conflict of interests The authors declare no potential conflicts of interest with respect to the research, authorship, and/or publication of this article.

Open Access This article is licensed under a Creative Commons Attribution 4.0 International License, which permits use, sharing, adaptation, distribution and reproduction in any medium or format, as long as you give appropriate credit to the original author(s) and the source, provide a link to the Creative Commons licence, and indicate if changes were made. The images or other third party material in this article are included in the article's Creative Commons licence, unless indicated otherwise in a credit line to the material. If material is not included in the article's Creative Commons licence and your intended use is not permitted by statutory regulation or exceeds the permitted use, you will need to obtain permission directly from the copyright holder. To view a copy of this licence, visit http://creativecommons.org/licenses/by/4.0/. 


\section{References}

Alm Fjellborg, A. (2018). Housing tenure and residential mobility in Stockholm 1990-2014. Uppsala University.

Andersson, R. (2013). Reproducing and Reshaping Ethnic Residential Segregation in Stockholm: The Role of Selective Migration Moves. Geografiska Annaler: Series b, Human Geography, 95(2), 163-187

Andersson, R., \& Bråmå, Å. (2004). Selective migration in Swedish distressed neighbourhoods: can areabased urban policies counteract segregation processes? Housing Studies, 19(4), 517-539

Andersson, R., \& Bråmå, Å. (2018). The Stockholm estates-a tale of the importance of initial conditions, macroeconomic dependencies, tenure and immigration. In D. B. Hess, T. Tammaru, \& M. van Ham (Eds.), Housing Estates in Europe. Poverty, Ethnic Segregation and Policy Challenges (pp. 361-387). Springer.

Andersson, R., \& Hedman, L. (2016). Economic decline and residential segregation: a Swedish study with focus on Malmö. Urban Geography, 37(5), 748-768

Andersson, R., \& Kährik, A. (2016). Widening gaps: Segregation dynamics during two decades of economic and institutional change in Stockholm. In Tiit Tammaru, S. Marcińczak, M. Van Ham, \& S. Musterd (Eds.), Socio-Economic Segregation in European Capital Cities. East meets West. (pp. 110131). London and New York: Routledge.

Andersson, R., \& Magnusson Turner, L. (2014). Segregation, gentrification, and residualisation: from public housing to market-driven housing allocation in inner city Stockholm. International Journal of Housing Policy, 14(1), 3-29

Backvall, K. (2019). Constructing the Suburb. Swedish discourses of Spatial Stigmatisation. Uppsala University.

Bailey, N., van Gent, W. P. C., \& Musterd, S. (2017). Remaking urban segregation: Processes of income sorting and neighbourhood change. Population, Space and Place, 23(3), e2013.

Bolt, G., van Kempen, R., \& van Ham, M. (2008). Minority Ethnic Groups in the Dutch Housing Market: Spatial segregation, relocation dynamics and housing policy. Urban Studies, 45(7), 1359-1384

Boterman, W. R. (2012). Deconstructing coincidence: How middle-class households use various forms of capital to find a home. Housing, Theory and Society, 29(3), 321-338

Boterman, W. R., \& van Gent, W. P. C. (2014). Housing liberalisation and gentrification: The social effects of tenure conversions in Amsterdam. Tijdschrift Voor Economische En Sociale Geografie, $105(2), 140-160$

Bråmå, A. (2006). 'White flight'? The production and reproduction of immigrant concentration areas in Swedish cities, 1990-2000. Urban Studies, 43(7), 1127-1146

Bråmå, Å., \& Andersson, R. (2005). Who leaves Sweden's large housing estates. In R. Van Kempen, K. Dekker, S. Hall, \& I. Tosics (Eds.), Restructuring large housing estates in Europe. (pp. 169-192). The Policy Press.

Bråmå, Å., \& Andersson, R. (2010). Who leaves rental housing? Examining possible explanations for ethnic housing segmentation in Uppsala, Sweden. Journal of Housing and the Built Environment, 25(3), 331-352

Brown, L. A., \& Moore, E. G. (1970). The intra-urban migration process: a perspective. Geografiska Annaler: Series b, Human Geography, 52(1), 1-13

Christophers, B. (2013). A monstrous hybrid: The political economy of housing in early twenty-first century Sweden. New Political Economy, 18(6), 885-911

Christophers, B. (2018). Intergenerational inequality? Labour, capital, and housing through the ages. Antipode, 50(1), 101-121

Clark, W. A. V. (1992). Residential preferences and residential choices in a multiethnic context. Demography, 29(3), 451-466

Clark, W. A. V., \& Coulter, R. (2015). Who wants to move? The role of neighbourhood change. Environment and Planning A, 47(12), 2683-2709

Clark, E., \& Hedin, K. (2009). Circumventing circumscribed neoliberalism: The "system switch" in Swedish housing. (S. Glynn, Ed.)Where the other half lives: Lower income housing in a neoliberal world. London: Pluto Press.

Clark, W. A. V., \& Onaka, J. L. (1983). Life cycle and housing adjustment as explanations of residential mobility. Urban Studies, 20(1), 47-57

Clark, W. A. V., Deurloo, M., \& Dieleman, F. (2006). Residential mobility and neighbourhood outcomes. Housing Studies, 21(3), 323-342

Crowder, K. (2000). The racial context of white mobility: An individual-level assessment of the white flight hypothesis. Social Science Research, 29(2), 223-257 
Dean, J., \& Hastings, A. (2000). Challenging images: Housing estates, stigma and regeneration. The Policy Press.

Dekker, K., \& Van Kempen, R. (2004). Large Housing Estates in Europe: Current situation and developments. Tijdschrift Voor Economische En Sociale Geografie, 95(5), 570-577

Doucet, B. (2014). A process of change and a changing process: Introduction to the special Issue on Contemporary Gentrification. Tijdschrift voor economische en sociale geografie, 105(2), 125-139.

Elander, I. (1991). Good dwellings for all: The case of social rented housing in Sweden. Housing Studies, 6(1), 29-43

Ellen, I. G. (2000). Race-based neighbourhood projection: A proposed framework for understanding new data on Racial Integration. Urban Studies, 37(9), 1513-1533

Feijten, P., \& van Ham, M. (2009). Neighbourhood Change... Reason to Leave? Urban Studies, 46(10), 2103-2122.

Finney, N., \& Simpson, L. (2009). "Sleepwalking to segregation”? Challenging myths about race and migration. The Policy Press.

Friedrichs, J. (1991). Middle-class leakage in large new housing estates: Empirical findings and policy implications. Journal of Architectural and Planning Research, 8(4), 287-295

Galster, G. (2001). On the nature of neighbourhood. Urban Studies, 38(12), 2111-2124

Galster, G., \& Sharkey, P. (2017). Spatial Foundations of Inequality: A Conceptual Model and Empirical Overview. RSF: The Russell Sage Foundation Journal of the Social Sciences, 3(2), 1-33.

Galster, G., \& Turner, L. M. (2017). Status discrepancy as a driver of residential mobility: Evidence from Oslo. Environment and Planning a: Economy and Space, 49(9), 2155-2175

Goering, J. M. (1978). Neighborhood tipping and racial transition: A review of social science evidence. Journal of the American Institute of Planners, 44(1), 68-78

Grundström, K., \& Molina, I. (2016). From Folkhem to lifestyle housing in Sweden: segregation and urban form, 1930s-2010s. International Journal of Housing Policy, 16(3), 316-336

Harris, D. R. (1999). "Property values drop when blacks move in, because...": racial and socioeconomic determinants of neighborhood desirability. American Sociological Review, 461-479.

Hastings, A. (2004). Stigma and social housing estates: Beyond pathological explanations. Journal of Housing and the Built Environment, 19(3), 233-254

Hedin, K., Clark, E., Lundholm, E., \& Malmberg, G. (2012). Neoliberalization of Housing in Sweden: Gentrification, Filtering, and Social Polarization. Annals of the Association of American Geographers, 102(2), 443-463

Hedman, L., Manley, D., van Ham, M., \& Östh, J. (2015). Cumulative exposure to disadvantage and the intergenerational transmission of neighbourhood effects. Journal of Economic Geography, 15(1), 195-215

Hochstenbach, C. (2017). State-led gentrification and the changing geography of market-oriented housing policies. Housing, Theory and Society, 34(4), 399-419

Hochstenbach, C., \& Boterman, W. R. (2015). Navigating the field of housing: housing pathways of young people in Amsterdam. Journal of Housing and the Built Environment, 30(2), 257-274

Hochstenbach, C., \& Musterd, S. (2018). Gentrification and the suburbanization of poverty: changing urban geographies through boom and bust periods. Urban Geography, 39(1), 26-53

Johansson, T., \& Olofsson, R. (2011). The art of becoming 'Swedish': Immigrant youth, school careers and life plans. Ethnicities, 11(2), 184-201

Kadarik, K. (2020). Immigrants' mobility towards native-dominated neighbourhoods: the role of individual resources, country of origin, and settlement context. Geografiska Annaler: Series b, Human Geography, 102(2), 191-213

Kadarik, K., Miltenburg, E., Musterd, S., \& Östh, J. (2021). Country-of-origin-specific economic capital in neighbourhoods: Impact on immigrants' employment opportunities. Environment and Planning A: Economy and Space. . https://doi.org/10.1177/0308518X21989702

Kährik, A., \& Tammaru, T. (2010). Soviet Prefabricated Panel Housing Estates: Areas of Continued Social Mix or Decline? The Case of Tallinn. Housing Studies, 25(2), 201-219

Kauppinen, T. M., \& Vilkama, K. (2016). Entry to homeownership among immigrants: A decomposition of factors contributing to the gap with native-born residents. Housing Studies, 31(4), 463-488

Kearns, A., \& Parkes, A. (2003). Living in and leaving poor neighbourhood conditions in England. Housing Studies, 18(6), 827-851

Krysan, M., \& Crowder, K. (2017). Cycle of Segregation: Social Processes and Residential Stratification. Russell Sage Foundation.

Lee, B. A., Oropesa, R. S., \& Kanan, J. W. (1994). Neighborhood context and residential mobility. Demography, 31(2), 249-270 
Lees, L. (2008). Gentrification and social mixing: Towards an inclusive urban renaissance? Urban Studies, 45(12), 2449-2470

Macpherson, R. A., \& Strömgren, M. (2013). Spatial assimilation and native partnership: Evidence of Iranian and Iraqi immigrant mobility from segregated areas in Stockholm, Sweden. Population, Space and Place, 19(3), 311-328

Malmberg, B., Andersson, E., \& Östh, J. (2013). Segregation and Urban Unrest in Sweden. Urban Geography, 34(7), 1031-1046

Manley, D., Ham, M. Van, \& Hedman, L. (2018). Experienced and Inherited Disadvantage : A Longitudinal Study of Early Adulthood Neighbourhood Careers of Siblings. IZA Discussion Paper, (No. 11335).

Marcińczak, S., Musterd, S., van Ham, M., \& Tammaru, T. (2016). Inequality and rising levels of socioeconomic segregation. In T. Tammaru, S. Marcińczak, M. van Ham, \& S. Musterd (Eds.), Socio-Economic Segregation in European Capital Cities: East Meets West. (pp. 358-382). Routledge.

Miltenburg, E. M. (2015). The conditionality of neighbourhood effects upon Social neighbourhood embeddedness: A critical examination of the resources and socialisation mechanisms. Housing Studies, 30(2), 272-294

Mood, C. (2010). Logistic regression: Why we cannot do what we think we can do, and what we can do about it. European Sociological Review, 26(1), 67-82

Mulder, C. H. (1993). Migration dynamics: a life course approach. University of Amsterdam.

Musterd, S. (2005). Social and Ethnic segregation in Europe: Levels, causes, and effects. Journal of Urban Affairs, 27(3), 331-348

Musterd, S. (2008). Residents' views on social mix: Social mix, social networks and stigmatisation in Postwar Housing Estates in Europe. Urban Studies, 45(4), 897-915

Musterd, S. (2014). Public housing for whom? Experiences in an era of mature Neo-Liberalism: The Netherlands and Amsterdam. Housing Studies, 29(4), 467-484

Musterd, S., \& van Kempen, R. (2007). Trapped or on the springboard? Housing careers in large housing estates in european cities. Journal of Urban Affairs, 29(3), 311-329

Musterd, S., van Gent, W. P. C., Das, M., \& Latten, J. (2016). Adaptive behaviour in urban space: Residential mobility in response to social distance. Urban Studies, 53(2), 227-246

Öresjö, E., Andersson, R., Holmqvist, E., Pettersson, L., \& Siwertsson, C. (2004). Large housing estates in Sweden. Policies and practices. RESTATE report 3i. Utrecht: Faculty of Geosciences, Utrecht University.

Östh, J. (2014). Introducing the EquiPop software - an application for the calculation of k-nearest neighbour contexts/neighbourhoods. http://equipop.kultgeog.uu.se. http://equipop.kultgeog.uu.se

Phillips, D. (2006). Parallel Lives? Challenging Discourses of British Muslim Self-Segregation. Environment and Planning $d$ : Society and Space, 24(1), 25-40

Rossi, P. H. (1955). Why families move: a study in the social psychology of urban residential mobility. Glencoe (Ill.): Free Press.

Scarpa, S. (2016). Looking beyond the neighbourhood: income inequality and residential segregation in Swedish metropolitan areas, 1991-2010. Urban Geography, 37(7), 963-984

Schaake, K., Burgers, J., \& Mulder, C. H. (2010). Ethnicity at the individual and neighborhood level as an explanation for moving out of the neighborhood. Population Research and Policy Review, 29(4), 593-608

Schelling, T. C. (1969). Models of segregation. The American Economic Review, 59(2), 488-493

Sernhede, O. (2011). School, Youth Culture and Territorial Stigmatization in Swedish Metropolitan Districts. Young, 19(2), 159-180

Sharkey, P. (2008). The Intergenerational Transmission of Context. American Journal of Sociology, 113(4), 931-969

Søholt, S., \& Lynnebakke, B. (2015). Do immigrants' preferences for neighbourhood qualities contribute to segregation? The case of Oslo. Journal of Ethnic and Migration Studies, 41(14), 2314-2335

Speare, A. (1974). Residential satisfaction as an intervening variable in residential mobility. Demography, 11(2), 173-188

Tammaru, T., Marcińczak, S., van Ham, M., \& Musterd, S. (2016). Socio-Economic Segregation in European Capital Cities. Routledge.

Teernstra, A. B., \& Van Gent, W. P. C. (2012). Puzzling patterns in neighborhood change: Upgrading and downgrading in highly regulated Urban Housing Markets. Urban Geography, 33(1), 91-119

Turner, B., \& Whitehead, C. M. E. (2002). Reducing housing subsidy: Swedish housing policy in an international context. Urban Studies, 39(2), 201-217

van Ham, M., \& Clark, W. A. V. (2009). Neighbourhood mobility in context: Household moves and changing neighbourhoods in the Netherlands. Environment and Planning a: Economy and Space, 41(6), 1442-1459 
van Ham, M., \& Manley, D. (2012). Neighbourhood effects research at a crossroads. Ten challenges for future research Introduction. Environment and Planning A, 44(12), 2787-2793.

van Ham, M., Hedman, L., Manley, D., Coulter, R., \& Östh, J. (2014). Intergenerational transmission of neighbourhood poverty: an analysis of neighbourhood histories of individuals. Transactions of the Institute of British Geographers, 39(3), 402-417

van Kempen, R., Dekker, K., Hall, S., \& Tosics, I. (2005). Restructuring large housing estates in Europe: Restructuring and resistance inside the welfare industry. Policy Press.

Vartanian, T., Buck, P., \& Gleason, P. (2007). Intergenerational neighbourhood-type mobility: examining differences between blacks and whites. Housing Studies, 22, 833-856

Vogiazides, L. (2018). Exiting distressed neighbourhoods: The timing of spatial assimilation among international migrants in Sweden. Population, Space and Place, 24(8), e2169.

Vogiazides, L., \& Chihaya, G. K. (2020). Migrants' long-term residential trajectories in Sweden: persistent neighbourhood deprivation or spatial assimilation? Housing Studies, 35(5), 875-902

Wassenberg, F. (2004). Renewing stigmatised estates in the Netherlands: A framework for image renewal strategies. Journal of Housing and the Built Environment, 19(3), 271-292

Wessel, T., Andersson, R., Kauppinen, T., \& Andersen, H. S. (2017). Spatial integration of immigrants in Nordic cities: The relevance of spatial assimilation theory in a welfare state context. Urban Affairs Review, 53(5), 812-842

Publisher's Note Springer Nature remains neutral with regard to jurisdictional claims in published maps and institutional affiliations. 